\title{
Linguistik Forensik Ujaran Kebencian terhadap Artis Aurel Hermansyah di Media Sosial Instagram
}

\author{
Yunita Suryani ${ }^{1}$, Rika Istianingrum ${ }^{2}$, Siti Umi Hanik ${ }^{3}$ \\ Pendidikan Bahasa dan Sastra Indonesia, FKIP, Universitas PGRI Ronggolawe Tuban ${ }^{\mathbf{1}}$, \\ Pendidikan Bahasa dan Sastra Indonesia, FKIP, Universitas Balikpapan ${ }^{2}$, \\ Administrasi Pendidikan, Universitas Gresik ${ }^{3}$ \\ you.n1t4@gmail.com ${ }^{1}, \underline{\text { rika@uniba-bpn.ac.id }}{ }^{2}, \underline{\text { hany.akasah@gmail.com }}{ }^{3}$
}

DOI: https://doi.org/10.32528/bb.v6i1.4167

First received: 19-01-2021

Final proof received: $10-03-2021$

\begin{abstract}
ABSTRAK
Instagram merupakan salah satu akun media sosial online yang digunakan untuk menyampaikan pesan, baik dalam bentuk teks, gambar, audio, maupun video. Pesan yang disampaikan dapat bervariasi, bergantung maksud dan tujuan pemilik akun. Salah satunya adalah ujaran kebencian. Ujaran kebencian pemilik akun@mantanaurelhermansyahdalam bentuk teks bermaksud menghina dan mencemarkan nama baik Aurel Hermansyah, dan bertujuan merusak hubungan Aurel Hermansyah dengan Atta Halilintar yang sengaja di-tag atau ditandai akun instagramnya.Tujuan penelitian ini mendeskripsikan bentuk tindak tutur ilokusi-perlokusi, kalimat tabu, dan ujaran kebencian oleh pemilik akun @ mantanaurelhermansyah. Metode dalam penelitian ini padan ortografis.Hasil analisis data ditemukan: 1) tindak tutur ilokusi jenis direktif kategori bertanya, kalimat tabu kategori penghinaan dengan menyebut nama, ujaran kebencian kategori menghasut; 2) tindak tutur ilokusi jenis komisif kategori menawarkan dan tindak tutur ilokusi ekspresif kategori menyatakan perasaan, kalimat tabu kategori pelecehan seksual, ujaran kebencian kategori penghinaan; 3) tindak tutur ilokusi direktif kategori bertanya, kalimat tabu kategori perbuatan tidak senonoh, ujaran kebencian kategori menghasut; 4) tindak tutur ilokusi asertif kategori mengakui, kalimat tabu kategori pelecehan seksual, ujaran kebencian kategori penyebaran berita bohong penghinaan dan pencemaran nama baik. Tindak tutur perlokusi dari ujaran kebencian tersebut adalah Atta Halilintar memberikan komentarburuk dan berusaha mencari tahu siapa pemilik akun tersebut.
\end{abstract}

Kata Kunci: Ujaran Kebencian; Kalimat Tabu; Tindak Tutur

\section{ABSTRACT}

Instagram is an online social media account that is used to convey messages, both in the form of text, images, audio, and video. The message conveyed may vary, depending on the intent and purpose of the account 
ownr. One of them is hate speech. The hate speech of the @ mantanaurelhermansyah account owner in the form of text intends to insult and defame Aurel Hermansyah's good name, and is aimed at damaging the relationship between Aurel Hermansyah and Atta Halilintar who was intentionally tagged or marked on his Instagram account. The purpose of this research is to describe the forms of illocutionary perlocution speech acts, taboo sentences, and hate speech by the account owner@mantanaurelhermansyah. The methos in this study is orthographic equivalent. The results of the data analysis were: 1) the illocutionary speech act of the questioning category directive, taboo sentences in the insult category by mentioning names, hate speech in the inciting category; 2) illocutionary speech acts in the commisive category of offering and expressive illocutionary speech acts in the category of expressing feelings, taboo sentences in the category of sexual harassement, hate speech in the category of insult; 3) illocutionary speech acts with the questioning category directive, taboo sentences in the indecent act category, hate speech in the inciting category; 4) assertive illocutionary speech acts in the category of confessing, taboo sentences in the category of sexual harassement, hate speech in the category of spreading insulting lies and defamation. The perlocution speech act of hate speech was Atta Halilintar giving bad comments and trying to find out who owned the account.

\section{Keywords: Hate Speech; Taboo Sentences; Speech Act}

\section{PENDAHULUAN}

Ujaran seseorang dapat dilakukan baik secara lisan maupun tertulis. Jika secara lisan, ujaran tersebut terjadi secara langsung, bertatap muka dengan mitra tutur atau dilakukan oleh perseorangan ketika berbicara dengan dirinya sendiri seperti bergumam karena maksud dan tujuan tertentu, atau ketika seseorang sedang berdoa kepada Tuhannya. Sedangkan ujaran seseorang yang dilakukan secara tertulis adalah dengan menuliskan apa yang dia rasakan dan pikirkan ke dalam media tulis, baik itu buku atau media elektronik yang menyediakan fitur teks tulis. Seseorang dapat menuliskan apa saja dan membaca serta memperoleh informasi apapun dengan membaca teks hasil tulisan orang lain melalui media sosial online layar kaca seperti android dan tablet.

Pada kasus tertentu, pengaruh adanya teknologi elektronik dan komunikasi yang semakin canggih memungkinkan seseorang berbicara atau berujar seorang diri di hadapan kamera video atau menuliskannya di media elektronik layar kaca. Berdasarkan maksud dan tujuan seseorang berbicara dihadapan kamera video atau menuliskannya di media elektronik layar kacaagar dapat disimpan untuk kepentingan pribadi atau sengaja mengunggah dan membagikan kepada publik melalui media sosialonline. Media sosial onlineterhubung dengan ruang siber sehingga memungkinkan orang lain yang tidak mengenal pengunggah dapat melihat, membaca dan menyikapinya dengan memberikan komentar. 
Setiap orang memiliki kebebasan menyampaikan pikirannya melalui berbagai konteks, baik fisik, psikologis, maupun sosial, karena proses menyampaikan pikiran terjadi bukan pada sebuah ruang kosong. Jadi, segala pikiran yang disampaikan dalam bentuk pesan memiliki fungsi sebagai alat kendali, motivasi, informasi serta pengungkapan emosional (Robbins, 2014, hal. 310-311). Baik pengirim pesan maupun penerima pesan memiliki kebebasan dalam menyampaikan pikiran dan perasaannya.Pada konteks mengirim dan menerima pesan bertatap muka secara langsung, seseorang dapat mengendalikan diri secara emosional untuk menghindari konflik. Berbeda dengan mengirim dan menerima pesan melalui media sosial online. Pengirim maupun penerima dapat menyembunyikan identitas dirinya, sehingga secara emosional mereka dapat mengungkapkan pikiran dan perasaan tanpa ada pengendalian diri. Hal tersebut pada akhirnya dapat menimbulkan konflik.

Keberadaan media sosial dianggap memudahkan seseorang untuk menyampaikan pikiran atau perasaan kepada orang lain dengan lambang yang bermakna. Pada situasi tertentu, penggunaan media sosial dapat merubah sikap atau tingkah laku seseorang dan menimbulkan efek tertentu (Effendy, 2003, hal. 13). Hal tersebut tentu saja perlu menjadi perhatian setiap pengguna media sosial, bahwa pesan yang disampaikan melalui media sosial akan memiliki dampak atau efek yaitu berupa komentar dari publik. Dampak atau efek tersebut bervariasi, bisa komentar yang baik dan bisa juga komentar yang buruk.

Setiap orang yang memiliki akun di media sosial, dapat menyampaikan pikiran dan perasaanya. Meski mereka paham akan konsekuensinya, yaitu akan dibaca dan diberi komentar oleh orang lain. Namun tidak sedikit pemilik akun yang mengabaikan resiko lain, yaitu menyakiti orang lain dengan menghina, dan mencemarkan nama baik orang lain. Sedangkan UU ITE berlaku bagi pengguna akun media sosial yang melakukan tindakan tidak menyenangkan seperti mengujarkan kebencian pada orang lain, sehingga pelaku dapat dikenakan sanksi hukum tindak pidana.

Hukum online pencemaran nama baik dalam UU ITE pasal 27 ayat (3) bukan delik biasa ditinjau dari esensi delik penghinaan dan aspek historis. Di jelaskan, pencemaran nama baik merupakan perbuatan menyerang nama baik atau kehormatan seseorang yang memiliki dampak pada pencemaran atau perusakan nama seseorang atau pihak-pihak yang dirugikan. Konten dan konteks tuturan atau tulisan yang ditujukan kepada pihak tertentu merupakan perbuatan "menyerang" nama baik yang dipahami korban, karena merekalah yang merasakan dihina, terhina, dan terlecehkan (Sitompul, 2012, hal. 39). Ada hukum yang mengatur tentang pencemaran nama baik melalui media sosial online. Apabila setiap pengguna media sosial memahami hukum tersebut, maka kecil kemungkinan terjadi tindak pelanggaran.

Mereka yang menyampaikan pesan di ruang siber disebut netizen. Netizen dapat mengirim sekaligus menerima atau memberikan komentar. Netizen ada yang berlaku sebagai lovers atau pecinta subjek, dan haters atau pembenci subjek. Loversakan tampak pada ujaran mereka yang memuji, mendambakan, mengelu-elukan, bahkan membela subjek jika dihujat oleh haters. Sebaliknya, hatersakan tampak pada ujaran mereka yang 
mencela, menghina, berkata tidak senonoh, bahkan memfitnah dan mencemarkan nama baik subjek yang dibencinya.

Ujaran kebencian merupakan tindakan menyerang kehormatan pihak lain seperti menista, penghinaan, tuduhan, memfitnah, dan sebagainya melalui ucapan (Soesilo, 2013, hal. 225). Ujaran kebencian terhadap artis Aurel Hermasyah berupa penghinaan dan pencemaran nama baik dilakukan oleh seseorang melalui akun media sosial instagram @mantanaurelhermansyah dengan menggunakan kalimat tabu. Tabu adalah suatu hal yang dianggap memiliki daya atau kekuatan jika diucapkan atau dilakukan dan dipercayai dapat menimbulkan hal buruk sehingga memunculkan pantangan atau larangan. Daya atau kekuatan dari ucapan dan tindakan yang dianggap tabu dapat berupa ucapan atau tindakan tidak senonoh, kotor, tidak pantas atau tidak layak. Sedangkan ucapan atau tindakan tabu dipercayai dapat membahayakan dirinya dan orang lain.

Ucapan atau tindakan tabu dari seseorang kepada orang lain dapat dianalisis dengan pendekatan linguistik forensik. Linguistik forensik merupakan kajian multidisipliner, yaitu ilmu linguistik dan ilmu forensik. Subyantoro (2017, hal. 3) menyatakan bahwa linguistik forensik merupakan kajian penerapan ilmu linguistik dan ilmu hukum dengan ruang lingkup kajian: 1) bahasa sebagai produk hukum, 2) bahasa dalam proses peradilan, dan 3) bahasa sebagai alat bukti. Selanjutnya, Olsson (2008, hal. 3) linguistik forensik adalah hubungan antara bahasa, tindak kriminal, dan hukum yang di dalamnya termasuk penegak hukum, masalah hukum, perundang-undangan, perselisihan, atau proses hukum, bahkan perselisihan yang berpotensi melibatkan beberapa pelanggaran hukum yang ditujukan untuk mendapatkan penyelesaian hukum.

Menurut ahli linguistik forensik, setiap pengguna bahasa memiliki versi sendiri yang berbeda. Masing-masing berbicara, menulis, dengan asumsi idiolek tersebut menunjukkan identitas diri yang khas dan istimewa, baik secara lisan maupun tulisan. Hal tersebut memudahkan ahli linguistikforensikmelacak konsep yang mendasarinya. Setiap pengguna bahasa memiliki kosakata aktif yang banyak yang diperoleh dan digunakan selama bertahun-tahun, dan tentu berbeda dengan banyaknya kosakata yang dimiliki oleh orang lain. Pada prinsipnya, setiap penutur bisa menggunakan kosakata yang dimilikinya kapanpun, namun pada kenyataannya mereka cenderung memilih kosakata yang lebih disukai secara individual. Hal ini tentu saja bermanfaat untuk kepentingan sidik jari linguistik. Menurut sudut pandang linguistik forensik, ciri khas linguistik seseorang dapat digunakan untuk bahan penyidikan dan penyelidikan hukum, seperti tanda tangan, untuk mengidentifikasi pelaku pelanggaran hukum (Coulthard, Johnson, \& Wright, 2007). Kosakata dapat menjadi salah satu indikator dalam bahan penyidikan dan penyelidikan hukum. Salah satunya adalah kosakata jenis kalimat tabu.

Fershman (2011:139) dalam Encyclopedia Britannica mendefinisikan tabu sebagai larangan melakukan suatu hal dengan keyakinan bahwa sesuatu tersebut sakral, disucikan, berbahaya, dan terkutuk jika dilakukan oleh orang awam.Pengertian tabu mengalami perluasan makna positif dan negatif (Freud, 1913:90; Affini, 2017: 95). Kata tabu itu sendiri pada satu sisi dipahami sebagai suatu hal yang ditakuti, berisi kekuatan 
supranatural, sehingga perlu dihindari, atau agar kesuciannya tidak tersentuh manusia sehingga tercemar. Di sisi lain, dipahami sebagai suatu hal yang kotor sehingga dilarang untuk disentuh agar tidak menimbulkan penyakit atau marabahaya dengan sifat kejahatannya yang dikandungnya.

Penelitian terkait ujaran kebencian dilakukan oleh Ningrum (2018) berjudul Kajian Ujaran Kebencian di Media Sosial tersebut mendeskripsikan bentuk tindak ujaran kebencian di media sosial serta jenis tindak tutur ilokusi pada komentar netizen di facebook. Di temukan bentuk ujaran kebencian pada topik masalah politik, sosial, ekonomi, dan agama; tindak tutur ilokusi bentuk asertif 32,63\%, direktif 20,63\%, komisif 9,26\%, ekspresif 35,9\%, dan deklaratif 1,58\%. Rahman (2019) dalam penelitiannya yang berjudul Penggunaan Kata Tabu di Media Sosial: Kajian Linguistik Forensik mendeskripsikan tipe-tipe kata tabu yang digunakan warganet di media sosial. Di temukan adanya kata-kata cabul, bahasa vulgar, dan penyebutan nama dan hinaan. Katakata tabu yang ditemukan berpotensi melanggar hukum tentang UU ITE dan KUHP tentang penghinaan.

Pada penelitian ini, tabu merujuk pada ucapan atau kata-kata kotor, tidak senonoh, tidak pantas atau tidak layak diucapkan oleh seseorang pada orang lain secara tertulis melalui akun media sosial dengan maksud memberikan informasi berupa berita negatif kepada publik. Ucapan tabu tersebut mengacu pada fisik atau anggota tubuh perempuan berupa pelecehan seksual dengan menjatuhkan harga diri artis Aurel Hermansyah yang ditulis oleh pemilik akun instagram@mantanaurelhermansyah.

Instagram merupakan salah satu akun media sosial yang sangat diminati oleh banyak kalangan. Instagram pada awalnya berkembang dari iPhone yang digunakan untuk berbagi foto. Data statistik menyebutkan, bahwa instagram telah menarik perhatian tujuh juta pengguna baru dan telah mengunggah sebanyak 150 juta foto dalam kurun waktu 10 bulan sejak aplikasi instagram diluncurkan (Frommer, 2010). Pengguna akun instagram tidak terbatas. Anak-anak hingga dewasa, dari masyarakat biasa hingga pejabat dan publik figur, dari masyarakat ekonomi menengah bawah hingga kelas atas. Pada penelitian ini, publik figur atau artis menjadi sasaran para netizen untuk dikomentari dalam bentuk sanjungan, kritikan, bahkan hinaan. Komentar-komentar tersebut ada yang menggunakan bahasa yang santun, namun tidak sedikit yang menggunakan kata-kata kasar. Kata-kata kasar yang ditemukan dalam penelitian iniberupa kalimat tabu.

Kata tabu memiliki beberapa kategori pengkalsifikasian yakni, mengutuk (cursing), kata tidak senonoh (profanity), menghujat (blashphemy), cabul (obscety), pelecehan seksual (sexual harassement), bahasa vulgar (vulgar language), penghinaan dengan menyebut nama(name calling and insult) (Jay, 2009, hal.140; Affini, 2017). Beberapa kategori kata tabu tersebut pada dasarnya bertujuan untuk melakukan tindakan pada arah kurang menghargai untuk seseorang. Kategori mengutuk memiliki tujuan menyakiti perasaan orang lain. Kategori mengucapkan kata tidak senonoh bertujun untuk menyalahgunakan sesuatu yang suci. Kata-kata menghujat bertujuan untuk mengkritik tempat ibadah serta tokoh agama. Kata cabul memiliki tujuan pikiran yang kotor dengan 
melanggar kesopanan. Kata-kata yang mengarah pada pelecehan seksual bertujuan untuk merendahkan orang lain melalui penampilan, perilaku, dan penyebutan jenis kelamin. Kata-kata dengan menggunakan bahasa vulgar yang dipengruhi budaya, kecerdasan, latar belakang ekonomi, dan nilai-nilai di dalam kehidupan masyarakat.

McMenamin menyatakan bahwa ilmu kebahasaan yang digunakan menangani kasus kebahasaan dapat melibatkan cabang ilmu linguistik seperti sosiolinguistik, pragmatik, semantik, fonologi, sebagai upaya penegakan hukum (McMenamin, 2002). Berdasarkan hal tersebut, penelitian ini mendeskripsikan bentuk ujaran kebencian dengan menggunakan kata-kata tabu yang dilakukan oleh seorang haters dari artis Aurel Hermansyah dengan kajian pragmatik tindak tutur ilokusi dan perlokusi.

Searle (seperti dikutip dalam Cummings, 2007, hal. 9) menyatakan bahwa tindak tutur tidak hanya tentang ujaran apa yang disampaikan (lokusi), namun lebih dari itu apa yang ada dibalik ujaran tersebut atau sedang mengharapkan apa seseorang mengujarkan itu (ilokusi). Selain itu, apa dampak yang ditimbulkan dari mitra tutur (perlokusi).Tindak tutur terbagi menjadi beberapa hal yakni, representatif atau asertif berupa pemberian kesaksian atas kebenaran suatu hal, direktif atau imposif berupa tindakan mitra tutur seperti yang diharapkan oleh penutur, ekspresif berupa ujaran evaluatif, komisif berupa sesuatu yang mengikat penutur terhadap mitra tutur, dan deklaratif merupakan bentuk penutur untuk menciptakan status, keadaan, serta kondisi (Searle, 1975, hal. 67-70).

\section{METODE PENELITIAN}

Penelitian ini menggunakan metode deskriptif kualitatif. Sumber penelitian ini berasal dari akun sosial media instagram. Penelitian ini bertujuan mendeskripsikan ujaran kebencian yang dilakukan oleh haters atau seseorang yang membenci Aurel Hermansyah. Selain ujaran kebencian, agar data tersebut valid maka didukung dengan konteks situasi pada saat ujaran tersebut diunggah. Pengumpulan data diperoleh dari tangkapan layar pemilik akun instagram@mantanaurelhermansyah yang diunggah dan tersebar di berbagai laman media sosial. Analisis data pada penelitian ini menggunakanteknik padan ortografis dengan alat penentunya perekam tulisan.

\section{PEMBAHASAN}

Pada awal bulan Juli tahun 2020, Aurel Hermansyah artis wanita yang juga anak seorang musisi terkemuka di Indonesia Anang Hermansyah mendapat perlakuan tidak menyenangkan dari seorang haters atau seseorang yang tidak menyukai Aurel Hermansyah. Perlakuan tidak menyenangkan tersebut berupa ujaran kebencian kategori pencemaran nama baik Aurel melalui akun jejaring sosial instagram @ mantanaurelhermansyah. Berikut tangkapan layar akun haters Aurel Hermansyah tersebut yang telah beredar di berbagai situs jejaring sosial. 


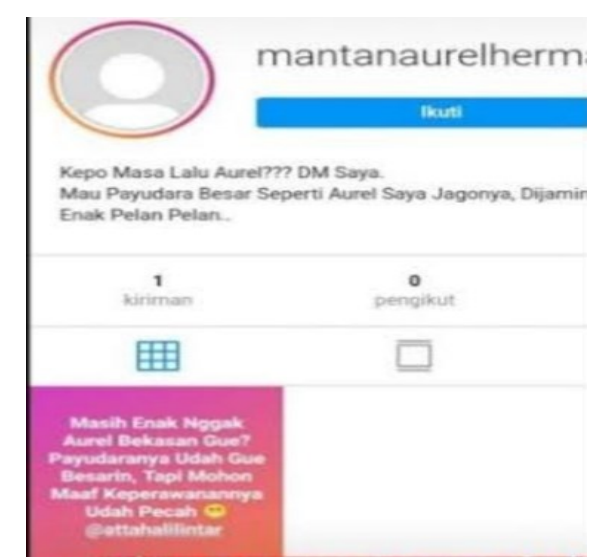

Sumber: Eny, 2020. https://www.kanal247.com/media/konten/0000057455.html

Gambar 1.Tangkapan Layar Akun Instagram@mantanaurelhermansyah

Pada akun instagram @mantanaurelhermansyah tersebut diketahui hanya terdapat satu unggahan. Hingga berita tersebut bergulir dan mendapat komentar dari para penggemar serta teman dekat Aurel Hermansyah. Atta Halilintar, teman dekat Aurel Hermansyah melakukan tangkapan layar terhadap unggahan haters dan menghujat dengan memberikan komentar buruk, hingga pada akhirnya Atta Halilintar kesulitan melacak akun tersebut karena telah dihapus oleh pemiliknya.

Ujaran kebencianditujukan kepada Aurel Hermansyah diunggah oleh pemilik akun@mantanaurelhermansyah beberapa saat setelah Aurel Hermansyah merayakan ulang tahunnya sekaligus dilamar oleh Atta Halilintar. Akun instagram Atta halilintar ditag atau ditandai oleh pemilik akun haters Aurel Hermansyah dengan maksud agar Atta Halilintar mengetahui dan membaca unggahannya. Namun pada Kamis, 16 Juli 2020 setelah Atta Halilintar membalas unggahan tersebut, akun@mantanaurelhermansyah sudah hilang atau dihapus.

Berikut bio yang ditulis oleh pemilik akun@mantanurelhermansyah pada jejaring sosial Instagram.

\section{Data 1}

\section{“Kepo Masa Lalu Aurel??? DM Saya.}

Ujaran Kepo Masa Lalu Aurel??Merupakan bentuk ilokusi jenis direktif kategori bertanya. Kalimat tersebut merupakan bentuk kalimat tanyaretoris tersamar dengan maksud tertentuyaitu mencari perhatian yang ditujukan kepada publik statusnya, dalam konteks tersebut ditujukan khususnya pada Atta Halilintar yang sengaja ditandai oleh pemilik akun.Selanjutnya, pemilik akun sekaligus memberikan jawaban DM Saya. Berdasarkan konteks, pemilik akun secara subjektif menyatakan diri mengetahui kehidupan masa lalu Aurel Hermasyah.

Ujaran pada data tersebut merupakan bentuk kalimat tabu kategori penghinaan dengan menyebut nama. Pemilik akun yang identitas dirinya tidak disebutkan,dengan sengaja bermaksud menghina dan mencemarkan nama baik Aurel Hermansyah melalui 
unggahannya yang seolah mengetahui latar belakang kehidupan masa lalu Aurel Hermansyah dan bersedia membagikannya pada publik.

Ujaran pada data tersebut merupakan bentuk ujaran kebencian kategori pencemaran nama baik. Pemilik akun memberikan opini kepada publik bahwa dia mengetahui latar belakang kehidupan masa lalu Aurel Hermansyah dan bersedia memberikan informasi tentang Aurel Hermansyah dengan tujuan yang tidak baik, yaitu menghina dan mencemarkan nama baik Aurel Hermansyah.

Data 2

\section{Mau Payudara Besar Seperti Aurel Saya Jagonya, Dijamin Enak Pelan- Pelan. “}

Ujaran Mau Payudara Besar Seperti Aurel Saya Jagonya, Dijamin Enak PelanPelan merupakan bentuk ilokusi jenis komisif kategori menawarkan.Ikon perempuan yang memiliki payudara besar identik dengan perempuan yang seksi dan menarik lakilaki. Pemilik akun menawarkan jasa dapat membuat payudara menjadi besar dengan memberikan bukti seperti payudara yang dimiliki Aurel Hermansyah.Selain itu, kalimatDijamin Enak Pelan-Pelan merupakan bentuk ilokusi ekspresif kategori menyatakan perasaan yang bersifat personal. Pemilik akun memberikan informasi mengenai sesuatu hal yang dirasakannya. Berdasarkan konteks, rasa enak bukan mengacu pada indera pengecapan seperti manis, asin, atau pahit melainkan mengacu pada cara, proses, atau tindakan yaitu dapat membuat payudara menjadi besar seperti payudara Aurel Hermansyah tanpa rasa sakit (tidak enak) karena dilakukan dengan pelan-pelan.

Kalimat tersebut merupakan kalimat tabu kategori pelecehan seksual yang dilakukan dengan maksud menghina atau mencemarkan nama baik Aurel Hermansyah pada publik melalui akun media sosial. Kalimat tabu tersebut mengacu pada bentuk fisik anggota badan yaitu payudara besar, dan rasa yang mengacu pada cara, proses, atau tindakan membuat payudara menjadi besar.

Ujaran pada data tersebut merupakan bentuk ujaran kebencian kategori penghinaan yang ditandai dengan menyerang kehormatan seseorang, menuduhkan suatu hal yang memalukan dengan maksud diketahui umum. Pemilik akun dengan sengaja secara tersurat menyampaikan kepada peublikjika dirinya memiliki keahlian atau jago membuat payudara menjadi besar dan memberikan jaminan dengan memberikan bukti pada data 4 bahwa dirinya yangtelah membuat payudara AurelHermansyah besar.

Selanjutnya, berikut postingan pemilik akun@mantanaurelhermansyah.

Data 3

\section{“Masih Enak Nggak Aurel Bekasan Gue?}

Bekasan berasal dari kata bekas dan mendapat akhiran -an. Bekas menurut KKBI online memiliki beberapa arti, di antaranya tanda yang tertinggal atau tersisa (sesudah 
dipegang, diinjak, dilalui, dan sebagainya), dan sudah pernah dipakai. Sedangkan akhiran -an pada kata bekasan, memiliki arti akibat atau hasil perbuatan. Kata bekasan dalam konteks tersebut memiliki arti pernah dipegang atau dipakai. Kata bekasan merujuk pada subjek yang disebut sebelumnya, yaitu Aurel Hermansyah.

Kalimat tersebut merupakan bentuk ilokusi direktif kategori bertanya. Pemilik akun dengan sengaja menandai akun instagram Atta Halilintar untuk memberikan pertanyaan kepada Atta Halilintar mengenai rasa setelah berhubungan badan dengan Aurel Hermansyah. Berdasarkan konteks, kalimat tersebut juga merupakan bentuk pernyataan dari pemilik akun bahwa Aurel Hermansyah pernah berhubungan badan dengannya.

Kalimat tanya tersebut merupakan bentuk kalimat tabu kategori perbuatan tidak senonoh. Pada kalimat tersebut, pemilik akun secara tersurat menuduh Atta Halilintar telah berhubungan badan dengan Aurel Hermansyah dengan bertanya mengenai rasa setelah berhubungan badan dengan Aurel Hermansyah. Pemilik akun juga menggunakan kata bekasan, dengan maksudmemberikan informasi bahwa Aurel Hermansyah pernah berhubungan badan dengannya seperti konteks kalimat pada data 4 .

Ujaran pada data tersebut merupakan bentuk ujaran kebencian kategori menghasut. Pemilik akun dengan sengaja menghasut Atta Halilintar dengan maksud agar Atta Halilintar berbuat sesuatu terhadap hubungannya dengan Aurel Hermansyah setelah tahu kebenaran jika Aurel Hermansyah pernah berhubungan badan dengan orang lain.

Data 4

\section{Payudaranya Udah Gue Besarin, Tapi Mohon Maaf Keperawanannya Udah Pecah (emoji tertawa)@attahalilintar”}

Data 4 merupakan bentuk ilokusi asertif kategori mengakui yang ditandai dengan piranti $u d a h$ atau sudah. Pemilik akun secara tersurat mengakui bahwa dirinya yang sudah atau telah membuat payudara Aurel Hermansyah menjadi besar. Selain itu, pada kalimat Keperawanannya Udah Pecah, pemilik akun memberikan pengakuan telah menodai atau merenggut keperawanan Aurel Hermansyah yang ditandai dengan pecahnya keperawanan atau selaput dara milik Aurel Hermansyah.

Pada data 4 tersebut terdapat kata Tapi yang merupakan kata penghubung pertentangan. Kata penghubung tapi, biasanya digunakan untuk menyatakan perbedaan suatu objek yang dibandingkan dengan meninggikan atau merendahkan objek tersebut. Namun, kata penghubung tapi pada kalimat tersebut bukan berupa menyatakan perbedaan suatu objek yang dibandingkan antara kebaikan dengan kekurangan, melainkan berupa perbandingan antara kekurangan dengan kekurangan yang dimiliki oleh objek yang sama. Hal tersebut dilakukan dengan tujuan untuk menegaskan kalimat sebelumnya, bahwa bagian tubuh yaitu payudara dan selaput dara yaitu keperawanan Aurel Hermansyah sudah pernah dipegang dan disetubuhi oleh pemilik akun@aurelhermansyah. 
Permohonan maaf pada kalimat tersebut merupakan bentuk ilokusi direktif. Berdasarkan konteks kalimat, permohonan maaf tersebut merupakan bentuk ingkar yang memiliki makna bahwa kesalahan yang dilakukan oleh pemilik akun adalah disengaja dengan maksud agar Atta Halilintar mengetahui kekurangan Aurel Hermansyah. Penambahan emoji tertawa diakhir kalimat tersebut semakin memperjelas maksud pemilik akun. Dia merasa puas telah menyampaikan kekurangan yang dimiliki Aurel Hermansyah kepada publik dan secara khusus menandai akun instagram Atta Halilintar.

Kalimat tersebut merupakan kalimat tabu kategori pelecehan seksual yang dilakukan dengan maksud mencemarkan nama baik Aurel Hermansyah pada publik melalui akun media sosial. Kalimat tabu tersebut mengacu pada bentuk fisik anggota badan yaitu payudara besar, dan rasa yang mengacu pada cara, proses, atau tindakan membuat payudara menjadi besar.

Ujaran pada data tersebut merupakan bentuk ujaran kebencian kategori penyebaran berita bohong karena tidak memiliki bukti otentik, penghinaan yang ditandai dengan menyerang kehormatan seseorang, menuduhkan suatu hal yang memalukan dengan maksud diketahui umum, serta pencemaran nama baik Aurel Hermansyah pada publik bahwa Aurel Hermansyah sudah tidak perawan karena keperawanannya telah direnggut laki-laki yang bukan suaminya.

Ujaran kebencian tersebut di atas dapat menggiring opini publik yang membaca, dan khususnya Atta Halilintar yang sengaja di-tag atau ditandai oleh pemilik akun agar membenci Aurel Hermansyah. Selain itu agar hubungan asmara Aurel Hermansyah dan Atta Halilintar berakhir, karena berdasarkan konteks situasi sebelum ujaran kebencian muncul, diketahui publik Atta Halilintar telah melamar Aurel Hermansyah. Perlokusi ujaran kebencian tersebut adalah Atta Halilintar melakukan tangkapan layar pada akun @ mantanaurelhermansyah kemudian menulis caption atau tanda teks berupa komentar Tiba2 Baca kaya gini, AKUN Ga Punya OTAK, OTAK DI DENGKUL dengan ikon tangan mengepal dan jempol menghadap ke bawah kemudian dia unggah di media sosial menunjukkan kekecewaannya pada pemilik akun@mantanaurelhermansyah.

Linguistik forensik ujaran kebencian ini merupakan tindak bahasa menyangkut hukum. Pemilik akun dengan ujaran kebenciannya, berupaya menyebarkan informasi yangdapat menimbulkan rasa kebencian dari orang lain.Ujaran kebencian @mantanaurelhermansyah berpotensi melanggar hukum tentang UU ITE dan KUHP tentang penghinaan. Jika pemilik akun tersebut dapat dilacak identitasnya, maka kasus ujaran kebencian tersebut dapat bergulir ke meja hijau.

\section{PENUTUP}

Kajian bahasa dengan pendekatan linguistik forensik di Indonesia sudah mulai berkembang. Kasus pencemaran nama baik melalui media sosial banyak ditemukan baik melalui akun facebook, instagram, maupun media sosial lainnya. Pada penelitian ini, kasus pencemaran nama baik terjadi pada akun media sosial instagram. Pelaku pencemaran nama baik melalui media sosial dapat dikenai sanksi hukum karena 
melakukan pelanggaran terhadap UU ITE. Pencemaran nama baik melalui akun media sosial dapat berupa penggunaan ucapan atau tindakan tabu. Ucapan atau tindakan tabu dalam penelitian ini dianalisis dengan tindak tutur.

\section{DAFTAR PUSTAKA}

Affini, L.N. (2017). Analisis Kata Tabu dan Klasifikasinya di Lirik Lagu Eminem pada Album The Marshal Mathers LP. Jurnal Lensa: Kajian Kebahasaan, Kesusastraan, dan Budaya. Vol. 7: 93-113.

Coulthard, M., Johnson, A., \& Wright, D. (2017). An Introduction to Forensic Linguistics: language in Evidence. London: Roudledge.

Cummings, L. (2007). Pragmatik Sebuah Perspektif Multidisipliner (1 ed.). (A.S.Ibrahim, Ed., E.

Setiawati, Sunoto, dkk, Trans.) Yogyakarta: Pustaka Pelajar.

Effendy, O.U., (2003). Ilmu, Teori, dan Filsafat Komunikasi. Bandung: Citra Aditya Bakti.

Fershman, C. (2011). Taboos and Identity: Considering the Unthinkable.American Economic Journal: Microeconomics. Vol. 3: 139-164.

Freud, S. (1913). Totem und Tabu: Einige Ubereinstimmungen im Seelenleben der Wilden und der Neurotiker. Jerman: Beacon Press.

Frommer, D. (2020, Juli 25). Here's How to Use Instagram. Business Insider dalam Wikipedia. https://id.wikipedia.org/wiki/Instagram.

Jay, T. (2009). The Utility and Ubiquity of Taboo Words. Massachusetts: Massachusetts College of Liberal Arts.

Kartini, E. (2020, Juli 20). Atta Halilintar Meradang Akun Bodong Sebut Aurel Hermansyah Tak Lagi

Perawan.https://www.kanal247.com/media/konten/0000057455.html.

McMenamin, G.R. (2002). Forensic Linguistics: Advances in Forensic Stylistics. Diambil dari https://books.google.co.id/books?i d=QA7OBQAAQBAJ.

Ningrum, S. W. (2018). Kajian Ujaran Kebencian di Media Sosial. Jurnal Ilmiah Korpus. Vol.2 No.3, hal. 241-252.

Olsson, J. (2008). Forensic Linguistics. New York: Continuum.

Rahman, N.I.Z. (2019) . Penggunaan Kata Tabu di Media Sosial: Kajian Linguistik Forensik. Jurnal Semiotika. Vol.20, No.2, hal.120-128.

Robbins, S.P., \& Judge, T.A. (2014). Perilaku Organisasi (16 ed.). Jakarta: Salemba Empat. 
Searle, J. R. (1975). Expression and Meaning: Studies in the Theory of Speech Act. Cambridge: Cambridge University Press.

Sitompul, J. (2012). Cyberspace, Cybercrimes, Cyberlaw: Tinjauan Aspek Hukum Pidana. Jakarta: Tatanusa.

Soesilo, R. (2013). Kitab Undang-undang Hukum Pidana (KUHP) Serta Komentarkomentarnya Lengkap Pasal Demi Pasal. Bogor: Politeia.

Subyantoro. (2017). Linguistik Forensik: Sebuah Pengantar. Semarang: Farishma Indonesia. 